\title{
PLANT SOURCES OF AMAZON ROSEWOOD OIL
}

\author{
José Guilherme S. Maia* and Eloisa Helena A. Andrade \\ Departamento de Engenharia Química e de Alimentos, Universidade Federal do Pará, 66075-900 Belém - PA, Brasil \\ Hilma Alessandra R. Couto \\ Embrapa Amazônia Ocidental, 69011-970 Manaus - AM, Brasil \\ Ana Carla M. da Silva \\ Secretaria de Educação, Governo Estadual do Pará, 66820-000 Belém - PA, Brasil \\ Friedhelm Marx and Christoph Henke \\ Department of Nutrition and Food Sciences, Food Chemistry I, University of Bonn, D53115 Bonn, Germany
}

Recebido em 29/11/06; aceito em 18/5/07; publicado na web em 5/10/07

\begin{abstract}
The aim of this study is to reevaluate the plant sources of the Amazon rosewood oil which have been named Aniba rosaeodora Ducke and Aniba duckei Kosterm. There is some disagreement on the exact botanical status of these species. Some Lauraceae specialists analyzing available material from both species concluded that there is no basis for regarding them as different. Based on our results we are confirming that the chemical composition of both species is quite different from that previously reported. So we are suggesting to bring back the previous botanical rosewood status as proposed by Adolph Ducke.
\end{abstract}

Keywords: Aniba rosaeodora; Aniba duckei; rosewood oil.

\section{INTRODUCTION}

Rosewood is a tall tree, reaching $30 \mathrm{~m}$ in height and $2 \mathrm{~m}$ in diameter, straight cylindrical trunk and yellow-brown bark. This well-shaped crown occupies the upper canopy. Flowering occurs October to February and fruiting November to March. The species changes its leaves during fruiting ${ }^{1}$.

The rosewood oil has a characteristics aroma and is a longestablished ingredient used in perfumes, fragrances and soaps. Linalool is their major constituent (80-90\%) which can be transformed into various derivatives of value to the flavor and fragrance industries ${ }^{2}$. In the last 30 years the exports of rosewood oil has experienced a long decline. Many elements have contributed for trade reduction. Plant sources exhaustion, logistics and costs of production, government regulations and synthetic linalool trade are the main factors.

Two plant sources have been attributed for the species producing the rosewood oil in the Amazon region: The Lauraceae Aniba rosaeodora Ducke and Aniba duckei Kosterm. There is some disagreement to the exact botanical status of these species. The $A$. rosaeodora species was identified by Adolph Ducke in 1927 but their previous commercial exploitation with the names of Ocotea caudata Koeller and Aniba parviflora (Meiss.) Mez was initiated in French Guiana since $1883^{3-5}$. The botanist Ducke believed that this species was confined to the Guianas, ranging from the Oyapoc River to Surinam. Collections of some samples from south of the Amazon River, between the municipalities of Juruti (Pará State, Brazil) and Maués (Amazonas state, Brazil), characterized by smaller leaves, were interpreted by Ducke as a geographical variety and identified as $A$. rosaeodora var. amazonica ${ }^{6}$. This variety was elevated to a specific rank as Aniba duckei by Kostermans in $1938^{7}$.

*e-mail: gmaia@ufpa.br

\#This paper is dedicated to Angela Maria Conte Leite (in memoriam), an enthusiastic scientist devoted to Amazon rosewood research, who was victim of an air craft accident in September 2006.
Kubitzki and Renner ${ }^{8}$ analyzing an available material from both species concluded that there is no basis for distinguishing these two entities. According them small-leaved forms also occur in the Guianas and large-leaved ones are present at north and south of Central Amazon ${ }^{8}$. Previously, Gottlieb and Mors ${ }^{9}$ isolated the flavanone pinocembrin from $A$. rosaeodora and the benzophenone cotoin from $A$. duckei and based in this chemical evidence they confirmed the occurrence of two different rosewood sources ${ }^{9,10}$. The incorporation of A. duckei in A. rosaeodora by Kubitzki and Renner ${ }^{8}$ take in account this chemical difference but it was unconsidered because pinocembrin and cotoin are nearly vinylogues compounds and the number of samples studied was small. Finally, these authors have suggested the investigation whether A. rosaeodora is differentiated into discrete chemical races or it exhibits clinal chemical variation.

The species Aniba fragrans Ducke is confused with rosewood plants. It is called "macacaporanga", whose oil have linalool as their main volatile compound but in minor content, ranging from 32 to $40 \%^{11}$ in comparison with many samples of rosewood oils analyzed by us at the request of the Amazon producers, varying from 78 to $93 \%{ }^{12}$. In the forest this species is very similar to young rosewood trees but for commercial exploitation its oil bouquet is not accepted as those of the traditional rosewood oils.

Since the time of Ducke and Kostemans, the oil producers and the wood collectors have distinguished some trivial types of rosewood according their appearances and oil contents. Among these morphological types they recognized regularly trees of "pau-rosa preciosa", "pau-rosa tachi", "pau-rosa itaúba" and "pau-rosa imbaúba". In compliance with the oil producers to distill one barrel of rosewood oil (180 liters) it will be necessary to use different quantities of wood chippings of "preciosa", "tachi”, "itaúba", and "imbaúba" types. The first two require minor quantities in comparison with the last two types. Distinct types of rosewood sources based in their appearance and oil content were cited in others reports ${ }^{13-15}$ but none study or tentative to attribute relationship between these popular types and both official botanical species were carried out. 
With the assistance of an oil producer and some field collectors the woods and leaves of "pau-rosa preciosa", "pau-rosa tachi", "paurosa itaúba" and "pau-rosa imbaúba" morphological types were collected in an area of Jatapu River, north of Central Amazon, in March 2002. To perform a seasonal study the leaf and wood samples of a rosewood tree growing in the Scientific Research Campus of Emílio Goeldi Museum, Belém (PA) were collected during one year (Sep/2001-Aug/2002). Additionally, another wood sample of an A. rosaeodora tree planted by Adolph Ducke in the Zoobotanical Park of Emílio Goeldi Museum, Belém (PA) was also collected.

This paper is a contribution for the better understanding of the rosewood oil plant sources and it is based in the GC, GC-MS and LC-MS analysis of authentic rosewood specimens and morphological types occurring in Central Amazon.

\section{EXPERIMENTAL}

\section{Material from rosewood samples}

A wood sample was collected from an exemplar of Aniba rosaeodora Ducke growing in the Zoobotanical Park of Emílio Goeldi Museum, located in the city of Belém, Pará State, Brazil. This specimen was planted in 1946 by the botanist Adolph Ducke, from which a voucher (\#17.710) is deposited in the herbarium of Emílio Goeldi Museum. This sample is identified in the paper as rosewood park.

Wood and leaf samples were collected from a rosewood specimen existing in the Scientific Research Campus of Emílio Goeldi Museum, Belém city, Pará State, Brazil. This rosewood specimen was identified as Aniba rosaeodora in comparison with the authentic species (voucher \#17.710) as above mentioned. The sample collection was started in September 2001 and extended for 12 months. These samples are identified in the paper as rosewood campus.

Wood and leaf samples were collected from four rosewood morphological types known as "pau-rosa preciosa" (PR-preciosa), "pau-rosa tachi" (PR-tachi), "pau-rosa itaúba" (PR-itaúba), and "pau-rosa imbaúba" (PR-imbaúba). The sample collection was made in March 2002 from specimens growing wild in the left side of Jatapu River, municipality of Novo Airão, Amazonas state, Brazil. The samples were naturally dried for 4 days while transported from the collection sites to the laboratory. By the same way, these rosewood morphological types were identified as Aniba rosaeodora in comparison with authentic species (voucher \#17.710). These samples are identified in the paper as rosewood morphological types.

\section{Sample preparation}

The air-dried and fresh samples were grinded and separated in 4 parts for hydrodistillation (100 g, $4 \mathrm{~h}$ ) using a Clevenger-type apparatus, for moisture determination $(5 \mathrm{~g}, 2 \mathrm{~h})$ using a Dean-Stark trap, for volatile simultaneous distillation-extraction (5 g, $30 \mathrm{~min}$ ) using a SPME device and $n$-pentane as solvent, and for ethanol extraction (75 g, $36 \mathrm{~h}$ ) using a Sohxlet extractor. The oils were dried over anhydrous sodium sulfate and their percentage content was calculated on basis of the plant dry weight. The moisture content of samples was calculated after the phase separation in the DeanStark traps. In the SPME device was used a $75 \mu \mathrm{m}$ carboxen/ polydimethylsiloxane fiber that was exposed during $30 \mathrm{~min}$ to plant sample flasks and then coupled to GC and GC-MS. The ethanolic extracts were submitted to vacuum evaporator to eliminate the solvent and their yields calculated.

The rosewood oil density was determined by the use of pycnometer (1 mL) according AOCS (Ja 11-48) official method, at $25^{\circ} \mathrm{C}$. The refractive index was obtained by the use of an Abbé refractometer. (Analytikjena) coupled to a thermostatic bath (Haake), at $25^{\circ} \mathrm{C}$. The specific rotation was determined by a polarimeter (241 Perkin-Elmer) using $1 \mathrm{~mL}$ chloroform oil $(20 \mu \mathrm{L})$ solution, at $25^{\circ} \mathrm{C}$.

\section{Analysis of the oil and extract constituents}

The qualitative analysis of the volatile compounds was performed on a Finnigan Mat INCOS XL GC-MS instrument, with the following conditions: a WCOT DB-5ms (30 m x $0.25 \mathrm{~mm} ; 0.25$ $\mu \mathrm{m}$ film thickness) fused silica capillary column; temperature programmed: $60-240{ }^{\circ} \mathrm{C}\left(3{ }^{\circ} \mathrm{C} / \mathrm{min}\right)$; injector temperature: $220{ }^{\circ} \mathrm{C}$; carrier gas: helium, adjusted to a linear velocity of $32 \mathrm{~cm} / \mathrm{sec}$ (measured at $100{ }^{\circ} \mathrm{C}$ ); injection types: the SPME device coupled directly to GC injector and splitless $(2 \mathrm{~mL}$, of a 1:1000 hexane sol.); split flow was adjusted to give a 20:1 ratio; septum sweep was a constant $10 \mathrm{~mL} / \mathrm{min}$; EIMS: electron energy, $70 \mathrm{eV}$; ion source temperature and connection parts: $180{ }^{\circ} \mathrm{C}$.

The quantitative data of oils and SPME concentrates were obtained by peak area normalization using a HP 5890 GC/FID operated under the same GC-MS conditions, except for the carrier gas that was hydrogen produced by a Packard hydrogen generator, and a WCOT CP-Sil CB (25 m x $0.25 \mathrm{~mm} ; 0.25 \mu \mathrm{m}$ film thickness) fused silica capillary column.

Individual components of oils and SPME concentrates were identified by comparison of both mass spectrum and their GC retention data with those of authentic compounds previously analyzed and stored in the data system. Other identification were made by comparison of mass spectra with those existing in the data system libraries and cited in the literature ${ }^{16}$. The retention indices were calculated for all volatiles constituents using an $n$ alkanes homologous series.

The ethanol extracts were analyzed by a Dionex Summit HPLC coupled to a LCQ Finnigan-Mat Ion Trap working with ElectroSpray Ionization and MS/MS and using a Phenomenex Aqua $3 \mu \mathrm{m}$ $\mathrm{C}_{18}$ column $(150 \times 2 \mathrm{~mm})$ eluted with the following solutions: A, $1 \%$ acetic acid in acetonitrile; $\mathrm{B}, 1 \%$ acetic acid in water.

\section{RESULTS AND DISCUSSION}

In the seasonal study of the specimen rosewood campus, collected in the campus of Emílio Goeldi Museum the leaf oil varied from $1.6 \%$ in September/October to $2.2 \%$ in March. The leaf oil variation was previously observed by us in an A. duckei specimen ${ }^{17}$ and it is connected with the plant phenology. The higher oil content occurs between November and May when the plant changes the old leaves. In the mentioned months the average yield was $2.0 \%$. The larger oil content in March (2.2\%) is noteworthy because it is in coincidence with the rainy season and the larger water precipitation. The rosewood oil yield resulting from commercial exploitation and offered by the international market ranges from 0.7 to $1.2 \%$. It is the half of the real oil yield existing in the plant due the field distilleries low efficiency, which is only 50\%. Looking for the higher oil yield occurring in March we think that the larger water precipitation affecting the oil cells could be a beneficial action to make easy their hydrodistilled separation. The oil yield and linalool content obtained from the seasonal study of rosewood campus are showed in Table 1.

Otherwise, the leaf age and the water precipitation affect the quality of oil. The older it is greater the percentage of $\alpha$-terpineol, terpinen-4-ol and linalool oxides that are products resulting from the plant oxidative process The younger it is, richer in linalool. The low linalool content observed in March (68.0\%) and April 
Table 1. The leaf oil yields and linalool contents resulted from the seasonal study of rosewood campus

\begin{tabular}{lccc}
\hline Sample & Collection Date & Oil $\%$ & Linalool \% \\
\hline PR-01 & Sep2001 & 1.6 & 90.5 \\
PR-02 & Out2001 & 1.6 & 88.1 \\
PR-03 & Nov2001 & 2.0 & 87.4 \\
PR-04 & Dec2001 & 2.0 & 96.1 \\
PR-05 & Jan2002 & 1.9 & 82.8 \\
PR-06 & Feb2002 & 1.9 & 84.2 \\
PR-07 & Mar2002 & 2.2 & 68.0 \\
PR-08 & Apr2002 & 2.0 & 74.8 \\
PR-09 & May2002 & 2.0 & 84.3 \\
PR-10 & Jun2002 & 1.7 & 91.2 \\
PR-11 & Jul2002 & 2.0 & 92.8 \\
PR-12 & Aug2002 & 1.9 & 86.6 \\
\hline
\end{tabular}

(74.8\%) could be related to the larger water circulation in the oilcontaining cells. Alcohols like linalool are more soluble and more easily eliminated.

The leaf and wood oil yields of the "preciosa", "tachi", "itaúba" and "imbaúba" rosewood morphological types were very distinguishable. In both, leaf and wood oils, the higher values were found for "preciosa" type (3.1 and 3.4\%, respectively). The smaller value for leaf oil was observed in the "imbaúba" type (2.4\%) while in the wood oil was the "itaúba" type (1.8\%). These results confirmed the field observation of the plant collectors regarding the rosewood popular types. In the prospective work and mapping of the trees that will be thrown down for commercial exploitation they have preference by the "preciosa" type if compared with the others types. According them to obtain a rosewood oil barrel $(180 \mathrm{~L})$ it will be necessary 12-13 t of "preciosa" wood chippings. The following yields were observed for the other types: $15-16$ t to obtain a "tachi" type oil barrel and 18-20 t for "itaúba" and "imbaúba" type oil barrels. The plant collectors recognized these types by their morphological aspects as wood and bark colors, leaf size, wood weight and leaf, bark and wood scents. The heavier woods known are "itaúba" and "tachi" types followed by "preciosa" and "imbaúba" types. The oil yield and values for density, refractive index and specific rotation of the rosewood morphological types are listed in Table 2. These physical properties are important specifications used in the International Market of Essential Oils and they were according with that previously reported ${ }^{4,13}$.

Table 2. Leaf and wood oil yields of rosewood morphological types and their physical properties

\begin{tabular}{lccccc}
\hline Samples & $\begin{array}{c}\text { Plant } \\
\text { Part }\end{array}$ & $\begin{array}{c}\text { Oil } \\
\%\end{array}$ & Density & $\begin{array}{c}\text { Refractive } \\
\text { Index }\end{array}$ & $\begin{array}{c}\text { Specific } \\
\text { Rotation }\end{array}$ \\
\hline PR-preciosa & Leaves & 3.1 & 0.9045 & 1.4669 & +0.189 \\
& Wood & 3.4 & 0.9070 & 1.4674 & +0.110 \\
PR-tachi & Leaves & 2.6 & 0.8920 & 1.4679 & +0.138 \\
& Wood & 2.9 & 0.8885 & 1.4660 & +0.112 \\
PR-itaúba & Leaves & 2.6 & 0.9000 & 1.4687 & +0.233 \\
& Wood & 1.8 & 0.9090 & 1.4710 & +0.056 \\
PR-imbaúba & Leaves & 2.4 & 0.9095 & 1.4690 & +0.207 \\
& Wood & 2.0 & 0.9035 & 1.4703 & +0.100 \\
\hline
\end{tabular}

Concerning the linalool content in the wood oils of rosewood morphological types was observed an inverted situation in comparison with the oil yields. The higher linalool content was found in the "PR-tachi" type oil (84.8\%) and the smaller one was observed in the "PR-preciosa" type oil (75.3\%). In the leaf oils the linalool content presented a small variation for the rosewood morphological types ranging from "PR-preciosa $(83.9 \%)$ to "PRitaúba" (79.7\%). Normally, in the field work the plant collectors choose the "PR-preciosa" type for their higher oil yield but they disown the discrepancy exhibited by their smaller linalool content comparing with the other morphological types. The international market of essential oils demanded rosewood oil at least with $85 \%$ of linalool and this fact could be the reason for sometime the barrel oil refusing. The GC-MS constituent analysis of the leaf and wood oils of rosewood park and the rosewood morphological types is showed in Tables 3 and 4. According Gottlieb and Kubitzki ${ }^{18}$ benzyl benzoate is nearly ubiquitous in Aniba species, except for linaloolrich rosewood specimens exported from Cayenne (Aniba rosaeodora Ducke) and from Belém (Aniba duckei Kosterm. $)^{8,18}$. On contrary this compound was found in all analyzed leaf and wood samples, as showed in the Tables 3 and 4 .

Based in the analysis of oil yield and linalool content existing in the rosewood park, rosewood campus and rosewood morphological types we observed a quantitative variability that could be a reflex of the environmental factors existing in the occurrence areas of rosewood plants.

The wood ethanol extracts furnished the following yields: rosewood campus, 11,4\%; rosewood park, 10,7\%, PR-preciosa, 10,6\%, PR-tachi, 10,3\%, PR-itaúba, 9,5\% and PR-imbaúba, 9,8\%. These ethanol extracts were analyzed by LC-MS-MS. In the LCMS chromatographic profile of ethanol extract of rosewood park, collected in the Zoobotanical Park of Emílio Goeldi Museum, was observed a low intensity peak with a molecular mass at 244 daltons emerging in $30.35 \mathrm{~min}$, that can be seen in the Figure 1. The benzophenone cotoin previously isolated from A. duckei Kosterm. by Gottlieb and Mors ${ }^{10,11}$ and their mass spectrum match very well with this peak. The compound was attributed to be cotoin. Other low intensity peak with a molecular mass at 260 daltons emerging in 21.97 min could be attributed to the derivative of cotoin carrying a phenolic hydroxyl in the A ring. Some high intensity peaks at 480 daltons were also observed in 40.7 and 44.9 min that were attributed to phenolic compounds of high molecular weight.

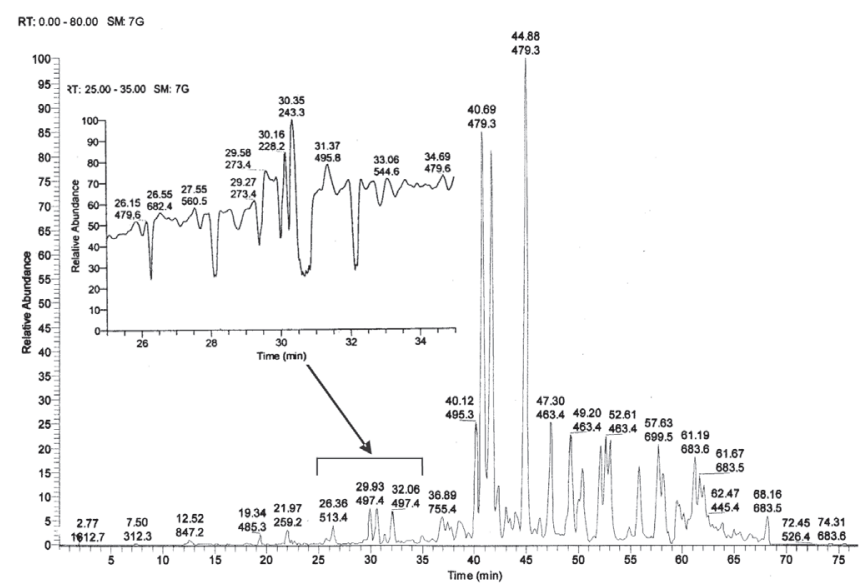

Figure 1. LC-MS chromatographic profile of ethanol extract of rosewood park showing the cotoin peak 244 (M-1) at $30.35 \mathrm{~min}$

In the LC-MS chromatographic profile of ethanolic extract of rosewood campus, collected in the Scientific Research Campus of Emílio Goeldi Museum, was observed a principal peak with a molecular mass of 256 daltons emerging in $34.0 \mathrm{~min}$, that can be seen in the Figure 2. The flavanone pinocembrin, previously isolated 
Table 3. Leaf oil constituents of rosewood park and rosewood morphological types

\begin{tabular}{|c|c|c|c|c|c|c|}
\hline Constituents & RI* & Rosewood park & PR-preciosa & PR-tachi & PR-itaúba & PR-imbaúba \\
\hline$\alpha$-pinene & 939 & 0.4 & 0.2 & 0.1 & $\operatorname{tr}$ & 0.2 \\
\hline$\beta$-pinene & 953 & 0.4 & & & 0.2 & $\operatorname{tr}$ \\
\hline limonene & 1029 & 0.1 & $\operatorname{tr}$ & $\operatorname{tr}$ & 0.1 & $\operatorname{tr}$ \\
\hline 1,8-cineol & 1031 & 0.5 & $\operatorname{tr}$ & $\operatorname{tr}$ & $\operatorname{tr}$ & $\operatorname{tr}$ \\
\hline trans-linalool oxide (furanoid) & 1074 & 0.8 & 1.7 & 1.1 & 1.5 & 1.7 \\
\hline cis-linalool oxide (furanoid) & 1088 & 0.7 & 1.5 & 1.2 & 1.3 & 1.6 \\
\hline linalool & 1098 & 85.5 & 83.9 & 82.1 & 79.7 & 79.8 \\
\hline trans-linalool oxide (pyranoid) & 1176 & 0.3 & $\operatorname{tr}$ & 0.1 & 0.1 & $\operatorname{tr}$ \\
\hline terpinen-4-ol & 1177 & 0.1 & $\operatorname{tr}$ & & & $\operatorname{tr}$ \\
\hline$\alpha$-terpineol & 1187 & 0.1 & $\operatorname{tr}$ & 0.1 & 0.1 & $\operatorname{tr}$ \\
\hline nerol & 1228 & 0.1 & $0.1 \mathrm{z}$ & $\operatorname{tr}$ & $\operatorname{tr}$ & $\operatorname{tr}$ \\
\hline geraniol & 1255 & 0.1 & 0.1 & $\operatorname{tr}$ & $\operatorname{tr}$ & $\operatorname{tr}$ \\
\hline$\alpha$-copaene & 1376 & 0.5 & 0.5 & 0.6 & 0.2 & $\operatorname{tr}$ \\
\hline$\beta$-caryophyllene & 1418 & 0.1 & $\operatorname{tr}$ & 0.4 & 0.2 & $\operatorname{tr}$ \\
\hline$\beta$-chamigrene & 1476 & $\operatorname{tr}$ & 0.3 & 0.1 & 0.2 & $\operatorname{tr}$ \\
\hline$\beta$-selinene & 1488 & 0.9 & 1.1 & 1.1 & 1.6 & 1.4 \\
\hline$\alpha$-selinene & 1496 & 0.4 & 1.0 & 1.0 & 1.4 & 1.1 \\
\hline$(E)$-nerolidol & 1564 & $\operatorname{tr}$ & $\operatorname{tr}$ & 0.3 & 0.4 & 0.3 \\
\hline spathulenol & 1576 & 0.7 & $\operatorname{tr}$ & 2.0 & 3.2 & 4.4 \\
\hline caryophyllene oxide & 1581 & 0.8 & 2.0 & 2.0 & & 1.6 \\
\hline humulene epoxide II & 1606 & & $\operatorname{tr}$ & 0.2 & & \\
\hline$\alpha$-muurolol & 1645 & $\operatorname{tr}$ & & & 0.7 & $\operatorname{tr}$ \\
\hline$\alpha$-cadinol & 1653 & & 0.5 & 0.6 & & 0.6 \\
\hline minor oxigenated sesquiterpenes & $1655-1764$ & 4.3 & 5.8 & 4.5 & 5.8 & 5.0 \\
\hline benzyl benzoate & 1762 & 0.2 & 0.5 & 0.3 & 0.1 & 0.4 \\
\hline Total & & 97.0 & 99.1 & 97.7 & 96.7 & 98.0 \\
\hline
\end{tabular}

$* \mathrm{RI}=$ Retention Index, $\operatorname{tr}=$ trace

Table 4. Wood oil constituents of rosewood park and rosewood morphological types

\begin{tabular}{|c|c|c|c|c|c|c|}
\hline Constituents & RI* & Rosewood park & PR-preciosa & PR-tachi & PR-itaúba & PR-imbaúba \\
\hline$\alpha$-pinene & 939 & 0.1 & 0.2 & 0.5 & 0,4 & 0.1 \\
\hline benzaldehyde & 959 & 0.2 & & & $\operatorname{tr}$ & 0.4 \\
\hline$\beta$-pinene & 978 & 0.3 & & & $\operatorname{tr}$ & $\operatorname{tr}$ \\
\hline limonene & 1031 & 0.7 & $\operatorname{tr}$ & 0.3 & 0.2 & 0.1 \\
\hline 1,8-cineol & 1033 & 0.3 & & & 0.8 & 0.2 \\
\hline$(Z)$ - $\beta$-ocimene & 1039 & 0.2 & 0.1 & 0.2 & & \\
\hline (E)- $\beta$-ocimene & 1050 & $\operatorname{tr}$ & 0.2 & $\operatorname{tr}$ & 0,1 & $\operatorname{tr}$ \\
\hline trans-linalool oxide (furanoid) & 1074 & 0.7 & 2.6 & 1.8 & 0.7 & 1.6 \\
\hline cis-linalool oxide (furanoid) & 1088 & 0.6 & 2.7 & 1.8 & 0.5 & 1.7 \\
\hline linalool & 1098 & 84.8 & 75.3 & 84.8 & 78.9 & 76.9 \\
\hline trans-linalool oxide (piranoid) & 1176 & $\operatorname{tr}$ & 0.3 & $\operatorname{tr}$ & $\operatorname{tr}$ & 0.1 \\
\hline terpinen-4-ol & 1177 & $\operatorname{tr}$ & $\operatorname{tr}$ & $\operatorname{tr}$ & $\operatorname{tr}$ & $\operatorname{tr}$ \\
\hline$\alpha$-terpineol & 1188 & 2.9 & 5.6 & 0.7 & 0.7 & 3.8 \\
\hline nerol & 1228 & 0.3 & 0.4 & $\operatorname{tr}$ & $\operatorname{tr}$ & 0.2 \\
\hline geraniol & 1255 & 1.0 & 1.8 & 0.3 & 0.1 & 1.0 \\
\hline$\alpha$-copaene & 1376 & 0.4 & 0.4 & $\operatorname{tr}$ & $\operatorname{tr}$ & $\operatorname{tr}$ \\
\hline$\beta$-elemene & 1391 & 0.3 & $\operatorname{tr}$ & $\operatorname{tr}$ & 0.6 & $\operatorname{tr}$ \\
\hline$\beta$-caryophyllene & 1418 & $\operatorname{tr}$ & $\operatorname{tr}$ & $\operatorname{tr}$ & $\operatorname{tr}$ & $\operatorname{tr}$ \\
\hline$\alpha$-humulene & 1454 & $\operatorname{tr}$ & $\operatorname{tr}$ & $\operatorname{tr}$ & $\operatorname{tr}$ & $\operatorname{tr}$ \\
\hline alloaromadendrene & 1462 & 0.1 & $\operatorname{tr}$ & $\operatorname{tr}$ & 0.2 & $\operatorname{tr}$ \\
\hline$\beta$-selinene & 1489 & 0.7 & 0.5 & 0.7 & 1.0 & 0.5 \\
\hline$\alpha$-selinene & 1496 & 0.6 & 0.4 & 0.6 & 0.9 & 0.4 \\
\hline (E)-nerolidol & 1564 & 0.2 & $\operatorname{tr}$ & 0.1 & 0.2 & $\operatorname{tr}$ \\
\hline spathulenol & 1576 & $\operatorname{tr}$ & $\operatorname{tr}$ & $\operatorname{tr}$ & $\operatorname{tr}$ & $\operatorname{tr}$ \\
\hline caryophyllene oxide & 1581 & 0.1 & $\operatorname{tr}$ & $\operatorname{tr}$ & $\operatorname{tr}$ & $\operatorname{tr}$ \\
\hline 1-epi-cubenol & 1627 & $\operatorname{tr}$ & & & 0.5 & $\operatorname{tr}$ \\
\hline epi- $\alpha$-muurolol & 1641 & $\operatorname{tr}$ & & & $\operatorname{tr}$ & 0.2 \\
\hline epi- $\alpha$-cadinol & 1642 & $\operatorname{tr}$ & 0.2 & 0.3 & $\operatorname{tr}$ & $\operatorname{tr}$ \\
\hline minor oxigenated sesquiterpenes & $1655-1726$ & 3.4 & 3.8 & 4.7 & 9.0 & 6.6 \\
\hline benzyl benzoate & 1762 & 0.6 & 2.3 & 1.2 & 2.7 & 3.7 \\
\hline Total & & 98.5 & 96.7 & 97.9 & 97.5 & 97.4 \\
\hline
\end{tabular}

$* \mathrm{RI}=$ Retention Index, $\operatorname{tr}=$ trace 


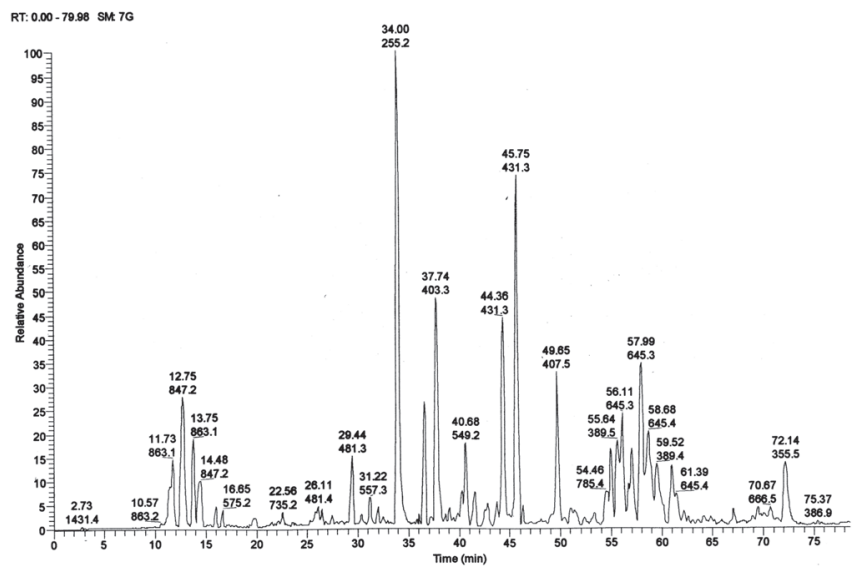

Figure 2. LC-MS chromatographic profile of ethanol extract of rosewood park showing the cotoin peak 256 (M-1) at $34 \mathrm{~min}$.

from the wood of A. rosaeodora by Gottlieb and Mors ${ }^{10,11}$ and their mass spectrum match very well with this peak. The mass spectrum showed also the fragment m/e 152 that was attributed to B-ring cleavage of the pinocembrin structure. Another evidence for this distinguishable extract was the peak at 390 daltons emerging in $55.64 \mathrm{~min}$, and their mass spectrum, which could be attributed to rubranine, a cytrilidene chalcone obtained also from A. rosaeodora ${ }^{19}$. Another minor intensity peaks with the molecular mass at 408 and 432 daltons can be attributed to 6-geranylnarigenin and apigeninhexoside, as proposed by the LC-MS data base system.

The chromatographic profile of ethanolic extracts of the four rosewood morphological types was very similar. At the same time they were also comparable to rosewood park, the specimen identified as A. rosaeodora in the Zoobotanical Park of Emílio Goeldi Museum. In these chromatographic profiles were observed peaks at molecular mass 244 and 260 daltons, emerging in 30.3 and 22.0 min, respectively. They are attributed to cotoin and hydroxycotoin as above mentioned.

Based in the analysis of the chemical composition of wood ethanol extracts of rosewood park, rosewood campus and rosewood morphological types we can observe a qualitative variability that could be due a genetic variation existing in the rosewood species.

\section{CONCLUSION}

From the LC-MS analysis of wood ethanol extracts we can affirm that the chemical composition of the rosewood park and the rosewood campus are quite distinguishable. The rosewood park and the four rosewood morphological types seem to belonging the same species, which was identified as Aniba rosaeodora by Adolph Ducke and planted by himself in the Zoobotanical Park of Emílio Goeldi Museum ${ }^{4}$. In these rosewood samples was observed the presence of benzophenone cotoin. Otherwise, in the rosewood campus was found the flavanone pinocembrin that could be attributed to A. duckei Kosterm ${ }^{8}$, previously identified as A. rosaeodora var. amazonica by Ducke 7 .

Therefore, following these chemical evidences and comparing the results with that previously obtained by Gottlieb and Mors ${ }^{10,11}$ we can deduce that they were inverted. Probably, the botanical identification of both rosewood samples worked by these two scientists was changed. On the other hand, it means which the taxonomic uncertainty with the rosewood species come from long time.

Analyzing this finding and reminding that A. duckei Kosterm is believed to be a synonym of $A$. rosaeodora Ducke var. amazonica we have in mind the occurrence of both A. rosaeodora Ducke and A. rosaeodora Ducke var. amazonica species, representing the rosewood plant. So that, we are suggesting to bringing back the previous botanical rosewood status proposed by Adolph Ducke ${ }^{3,6}$.

\section{ACKNOWLEDGEMENTS}

The authors are grateful to MCT/PPBio and CNPq for financial support and to Prof Braz Filho (UENF) to help us in the mass spectra analysis.

\section{REFERENCES}

1. Magalhães, L. M. S.; Alencar, J. C.; Acta Amazonica 1979, 9, 227.

2. Lawless, J.; The encyclopaedia of essential oils, Element: Shaftesbury, Dorset, 2000, p. 161.

3. Ducke, A.; Arch. Jard. Bot. Rio de Janeiro 1930, 5, 109.

4. SUDAM; Sudam Documenta 1972, 3, 5.

5. Marques, C. A.; Floresta e Ambiente 2001, 8, 195

6. Ducke, A.; Arch. Jard. Bot. Rio de Janeiro 1930, 5, 110.

7. Kostermans, A. J. G. H.; Recueil Trav. Bot. Néerl. 1938, 35, 924.

8. Kubitzki, K. ; Renner, M.; Flora Neotropica 1982, Monograph No. 31.

9. Gottlieb, O. R.; Mors, W. B.; J. Am. Chem. Soc 1958, 80, 2263.

10. Gottlieb, O. R.; Mors, W. B.; Bol. Inst. Quim. Agric. (Rio de Janeiro) 1958, 53,7 .

11. Maia, J. G. S.; Zoghbi, M. G. B.; Andrade, E. H. A.; Plantas aromáticas na Amazônia e seus óleos essenciais, Museu Paraense Emílio Goeldi: Belém, 2001.

12. Maia, J. G. S.; unpublished results.

13. Gottlieb, O. R.; Fineberg, M.; Guimarães, M. L.; Magalhães, M. T.; Maravalhas, N.; Perf. Essent. Oil Record 1964, 55, 253.

14. FAO Corporate Document Repository; Flavours and fragrances of plant origin, Forestry Department: Washington D.C., 1995.

15. May, P. H.; Barata, L. E. S.; Econ. Bot. 2004, 58, 257.

16. Adams, R. P.; Identification of Essential Oil Components by Gas Chromatography/Mass Spectroscopy, Allured Publishing Corporation: Carol Stream, 2001.

17. Araujo, V. C.; Corrêa, R. G. C.; Maia, J. G. S.; Silva, M. L.; Gottlieb, O. R.; Marx, M. C.; Magalhães, M. T.; Acta Amazonica 1971, 1, 45.

18. Gottlieb, O. R.; Kubitzki, K.; Biochem. Syst. Ecol. 1981, 9, 5.

19. Alleluia, I. B.; Braz Filho, R.; Gottlieb, O. R.; Magalhães, E. G.; Marques, R.; Phytochemistry 1978, 17, 517. 